\title{
Performance of two honey bee subspecies during harsh weather and Acacia gerrardii nectar-rich flow
}

\author{
Awad Mohamed Awad*, Ayman Ahmad Owayss, Abdulaziz Saad Alqarni
}

King Saud University/College of Food and Agriculture Sciences - Dept. of Plant Protection, Riyadh 11451, PO Box 2460 - Saudi Arabia.

*Corresponding author <amawad@ksu.edu.sa>

Edited by: Alberto Soares Corrêa

Received March 11, 2016

Accepted October 31, 2016

\begin{abstract}
Both climatic factors and bee forage characteristics affect the population size and productivity of honey bee colonies. To our knowledge, no scientific investigation has as yet considered the potential effect of nectar-rich bee forage exposed to drastic subtropical weather conditions on the performance of honey bee colonies. This study investigated the performance of the honey bee subspecies Apis mellifera jemenitica Ruttner (Yemeni) and Apis mellifera carnica Pollmann (Carniolan) in weather that was hot and dry and in an environment of nectar-rich flora. The brood production, food storage, bee population and honey yield of Yemeni (native) and Carniolan (imported) colonies on Talh trees (Acacia gerrardii Benth.), a nectar-rich, subtropical, and summer bee forage source in Central Arabia were evaluated. Owing to their structural and behavioral adaptations, the Yemeni bees constructed stronger (high population size) colonies than the Carniolan bees. Although both groups yielded similar amounts of Talh honey, the Yemeni bees consumed their stored honey rapidly if not timely harvested. $A$. $m$. jemenitica has a higher performance than A. m. carnica during extremely hot-dry conditions and A. gerrardii nectar-rich flow. Keywords: Apis mellifera jemenitica, bee forage, beekeeping, colony strengths subtropical
\end{abstract}

\section{Introduction}

Climatic factors and bee forage characteristics affect the performance and productivity of honey bee colonies. The most important factor affecting honey bee activities, i.e. honey production, is bee forage. Honeybees reap three benefits from plants: nectar, pollen and resin (Hill and Webster, 1995; Keasar and Shmida, 2009). However, hot and dry weather leads to unequal effects on the different subspecies of honey bees (Rachad and Parker, 1958; Corbet et al., 1993; Dag and Eisikowitch, 1999; Abrol, 2006; Alqarni, 2006; Ali, 2007).

Acacia gerrardii Benth. is a melliferous plant indigenous to Africa and the Middle East (Dharani, 2007) that provides numerous benefits to ecosystems including food for human consumption, stock pasture, traditional medicine, and honey bee forage (Al-Khalifa and Al-Arify, 1999; Aref et al., 2003; Dharani, 2007). Acacias are major sources of nectar and pollen for bees in the Arabian Peninsula (Alqarni et al., 2011). The Talh tree Acacia gerrardii blooms from May to Aug every year and produces a remarkable amount of nectar which is assumed to yield approximately $45 \mathrm{~kg}$ of honey per tree each season (Alqarni et al., 2015), making it one of the most common types of honey consumed in Saudi Arabia (Adgaba et al., 2012). In the subtropical zone, the nectarrich Talh flow enhances honey bee food collection flights despite the extremely hot-dry-windy weather. Moreover, honey bees play a valuable role in cross-pollinating Talh trees (Alqarni et al., 2016).

No previous data were available concerning the performance and productivity of honey bee colonies during the Talh bloom. Moreover, the effect of forage on the response of honey bee colonies to harsh conditions has not been discussed and has been poorly explored. In this study, the colony strength and honey productivity were evaluated in a native (Apis mellifera jemenitica) and an exotic (A. m. carnica) honeybee subspecies in Saudi Arabia, under extremely hot and dry conditions and $A$. gerrardii nectar flow.

\section{Materials and Methods}

\section{Study area}

The field investigations were carried out at Rawdhat-Khoraim, an oasis located in a vast subtropical desert in Central Arabia (25 $32^{\prime}$ North, 47 $17^{\prime}$ East, and 554 $\mathrm{m}$ altitude). It is approximately seven $\mathrm{km}^{2}$ in area. Its climate is type $B W h(B W$ refers to a desert climate with accumulated annual precipitation that is less than $50 \%$ of the potential evapotranspiration, while $h$ refers to a hot steppe or desert with an average annual temperature $\geq+18{ }^{\circ} \mathrm{C}$ ) according to the updated world map of the Köppen-Geiger climate classification (Peel et al., 2007). The Talh trees in Rawdhat-Khoraim constitute a prime tree population and are among the few floral species in the area (Alfarhan, 2001). The flowering season of Talh trees extends from May to Aug (Alqarni et al., 2015), and beekeepers annually move their hives to this region to harvest the valuable Talh honey.

The coinciding bee flora was initially tested during 2011 in a field survey. Rough data were collected to standardize the methods that were then followed in the two successive years. In addition to Talh trees, only two other flowering plant species were found to be present, and only in low densities: Ziziphus nummularia (Rham- 
naceae) and Calotropis procera (Apocynaceae) (Nuru et al., 2016). Consequently, Talh is the prevalent honey bee forage source in this subtropical area with its hot-drywindy weather conditions. The field investigations for the present study were carried out for two consecutive years, 2012 and 2013, from May to Aug.

The values of weather factors during the Talh nectar flow season of 2012 and 2013 were extracted from weather data provided by the nearest weather station which is approximately $50 \mathrm{~km}$ southwest of the study area. The flowering season of Talh trees in the study area coincides with extremely hot-drywindy weather. The minimum, maximum and average values of temperature and relative humidity were $22{ }^{\circ} \mathrm{C}, 47^{\circ} \mathrm{C}$, and $35^{\circ} \mathrm{C}$, and $4 \%, 36 \%$, and $11 \%$, respectively. The average wind speed throughout the season was $12 \mathrm{~km} \mathrm{~h}^{-1}$ and the temperature in 2013 $\left(33^{\circ} \mathrm{C}\right)$ was slightly lower than that in $2012\left(36^{\circ} \mathrm{C}\right)$ during the Talh nectar flow.

\section{Tested Honey bees}

Performance (colony strength) and productivity (honey production) during the Talh nectar flow season were evaluated on two honey bee subspecies: the Yemeni honey bee (Apis mellifera jemenitica Ruttner), a native subspecies of Saudi Arabia, and the Carniolan honey bee (A. m. carnica Pollmann), which is European in origin but is often imported from Egypt to Saudi Arabia. These subspecies were selected because they are the most commonly reared honey bees in Saudi Arabia. These bees were intended to represent two groups: native bees that have high adaptation (Yemeni) and exotic bees of less adaptation (Carniolan) to this harsh environment.

Twenty similar colonies were tested (five colonies/ subspecies/season). The queens were replaced during the second season because the Carniolan bees die after one season of honey harvesting in Central Arabia (Alqarni et al., 2011; Adgaba et al., 2014). All the queens used were 1 year old. The colonies selected were hived in modified Langstroth hives (7 frames capacity) and placed together under sunshades in the Rawdhat-Khoraim a few days before the Talh flowering start.

\section{Brood rearing and food storage}

Measurements of sealed worker brood, bee bread, and sealed honey were recorded for the tested honey bee colonies every 12 days. These tests were performed from May to Aug (the flowering season of Talh trees) in 2012 and 2013 using a standard wire frame divided into square centimeters (Jeffree, 1958).

\section{Bee population}

The number of combs covered with bees on both sides was recorded in each tested colony every 12 days. Adult bee populations were estimated in groups of 1100 adult workers, which is the number of bees that can occupy one side of a fully occupied Langstroth frame (Buco et al., 1987).

\section{Honey yield}

The amount of honey that could be harvested from each group was calculated using the values of the last two readings of the sealed honey area from the 2012 and 2013 seasons. In 2012, the last two stored honey readings were taken on 30 July and 11 Aug, while in 2013, they occurred on 7 Aug and 19 Aug. In each year, the aforementioned two readings were a few days before and after the end of the Talh flowering season, respectively. The honey volume was based on the observed area $\left(\mathrm{cm}^{2}\right)$ and the cell depth, evaluated at $1 \mathrm{~cm}$ on average. Next, the honey weight was calculated using the formula for honey amount which is the honey volume $\times 1.4115$, where 1.4115 is the average density value of Talh honey (Alqarni et al., 2012). In addition to the estimation of honey production, this procedure also evaluated the effect of delaying Talh honey harvesting on its mean yield.

\section{Statistical analysis}

Statistical testing and analysis were carried out using the SPSS 22 program. The data were first tested for normality and homogeneity using the KolmogorovSmirnov test and Levene's tests, respectively. When necessary, square roots were used to eliminate heterogeneity. Variation between means were tested using repeatedly measured ANOVA, and the values were then separated using Tukey's range test $(p<0.5)$. The factors tested were subspecies, month and year (Blocks).

\section{Results}

\section{Sealed brood}

The sealed brood production of the Yemeni colonies $\left(1529 \pm 70 \mathrm{~cm}^{2}\right.$ colony $\left.^{-1}\right)$ was higher than the Carniolan colonies $\left(932 \pm 62 \mathrm{~cm}^{2}\right.$ colony $\left.{ }^{-1}\right)\left(F_{1,168}=38.142\right.$, $p<0.001)$; in other words, the Yemeni colonies produced sealed brood at a rate 1.6 times greater than the Carniolan colonies. The Yemeni colonies reared 1.3, 1.5, 1.7, and 2.7 times more sealed brood than the exotic Carniolan colonies during May, June, July, and Aug, respectively. The sealed brood rearing rate was patterned according to subspecies, month, and year (Figure 1 and Table 1).

\section{Bee bread}

The Yemeni colonies stored $648 \pm 50 \mathrm{~cm}^{2}$ colony ${ }^{-1}$, which was 4.3 times $\left(F_{1,168}=355.072, p<0.001\right)$ the amount stored by the Carniolan colonies $(150 \pm 18$ $\mathrm{cm}^{2}$ colony $\left.{ }^{-1}\right)$. The bee bread storage rates varied subspecies, month, and year. The native colonies stored significantly higher amounts of bee bread compared to the Carniolan colonies during each month of Talh nectar flow \{(May: $\left.F_{1,38}=34.230, p<0.001\right)$ (June: $F_{1,38}=$ $21.316, p<0.001$ ) (July: $F_{1,58}=363.761, p<0.001$ ) (Aug: $\left.\left.F_{1,28}=107.437, p<0.001\right)\right\}$. The stored bee bread in native colonies was $3.0,3.6,4.0$ and 16.6 times greater than that in the imported colonies during May, June, July, and Aug, respectively (Figure 2 and Table 1). 
Table 1 - Seasonal values (mean \pm SE) of sealed worker brood rearing, food storage and bee population of Yemeni (Apis mellifera jemenitica) and Carniolan (A.m. carnica) honey bee colonies during Talh (Acacia gerrardii Benth.) nectar flow (May to Aug) in Central Arabia.

\begin{tabular}{lccccc}
\hline Season & Subspecies & Sealed Brood & Bee bread & Honey & Bee population \\
\hline \multirow{2}{*}{2012} & & $\mathrm{~cm}^{2}$ colony & & bees colony \\
& Yemeni & $1909 \pm 82^{* *}$ & $278 \pm 29^{* *}$ & $1920 \pm 212^{* *}$ & $11500 \pm 349^{*}$ \\
\hline \multirow{2}{*}{2013} & Carniolan & $618 \pm 79$ & $67 \pm 14$ & $648 \pm 108$ & $8475 \pm 134$ \\
\hline \multirow{2}{*}{$2012-2013$} & Yemeni & $1192 \pm 83$ & $976 \pm 56^{* *}$ & $1253 \pm 151$ & $11333 \pm 348$ \\
& Carniolan & $1212 \pm 73$ & $224 \pm 28$ & $2175 \pm 251^{*}$ & $11111 \pm 346$ \\
\hline
\end{tabular}

${ }^{*}$ Refers to a significant difference $(p<0.05)$ between the subspecies tested; ${ }^{*}$ Refers to a highly significant difference $(p<0.001)$ between the subspecies tested.
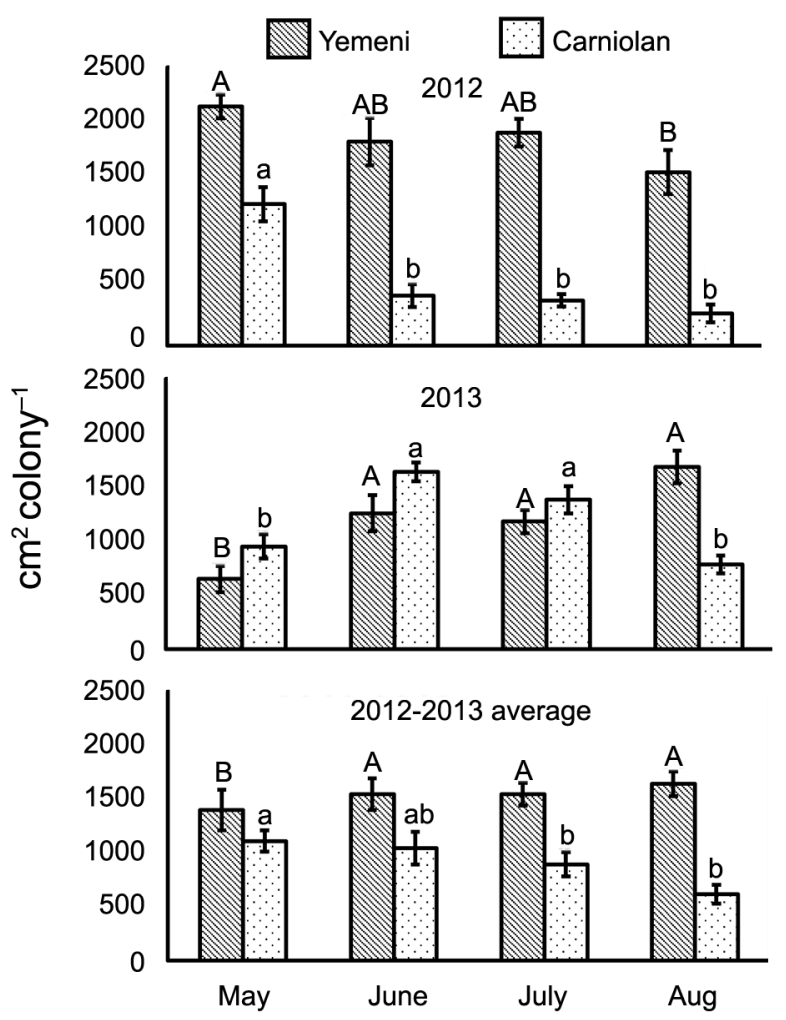

*Means with the same letter in the same column chart are not significantly different $(p>0.05)$

Figure 1 - Monthly values of sealed worker brood rearing rates (mean \pm standard error) of Yemeni (Apis mellifera jemenitica) and Carniolan (A.m. carnica) honey bee colonies during Talh (Acacia gerrardii Benth.) nectar flow season (May to Aug) in Central Arabia.

\section{Bee population}

The Yemeni colonies housed a significantly larger bee population $\left(F_{1,168}=33.226, p \leq 0.05\right)$ than the Carniolan colonies and produced worker bees at a rate 1.2 times greater than the Carniolan bees. The Yemeni subspecies built colonies at bee population rates 1.2 times higher than those of the Carniolan subspecies during each of June $\left(F_{1,38}=5.921, p<0.05\right)$, July $\left(F_{1,58}=29.009\right.$, $p<0.001)$, and Aug $\left(F_{1,28}=8.088, p<0.01\right)$. The tested

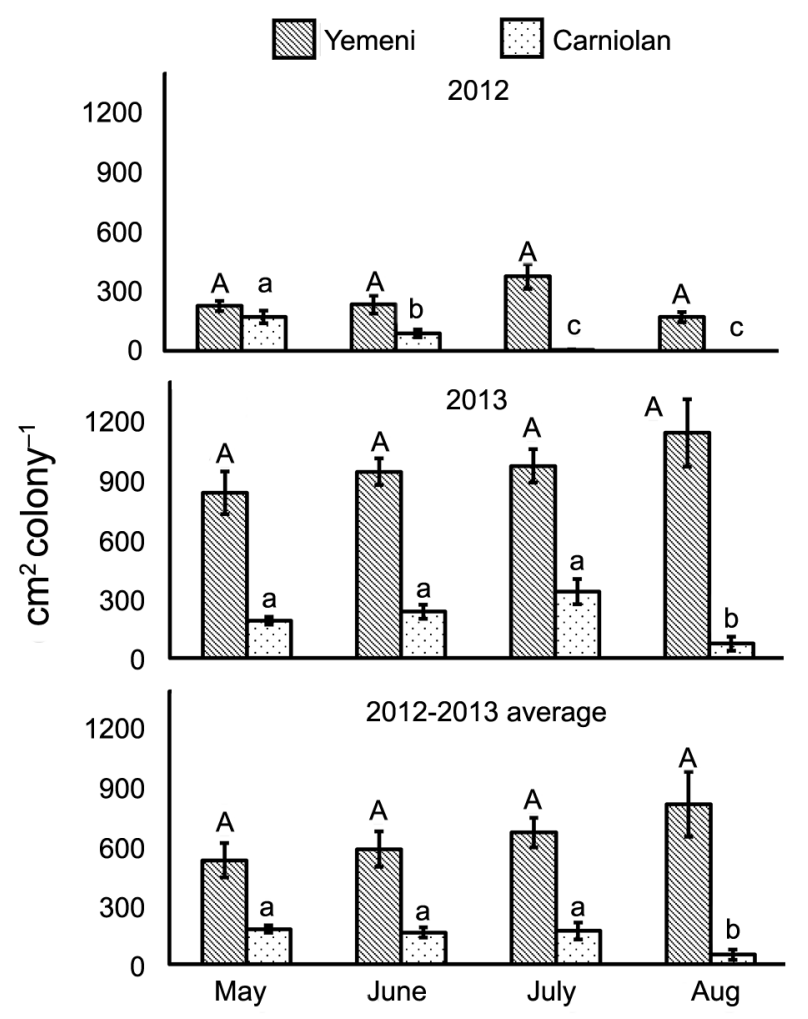

*Means with the same letter in the same column chart are not significantly different $(p>0.05)$.

Figure 2 - Monthly values of bee bread storage rates (mean \pm standard error) of Yemeni (Apis mellifera jemenitica) and Carniolan (A.m. carnica) honey bee colonies during the Talh (Acacia gerrardii Benth.) nectar flow season (May to Aug) in Central Arabia.

subspecies varied in bee population rates during Talh nectar flow in different months and in different years (Figure 3 and Table 1).

\section{Sealed honey}

The stocked honey areas were similar $\left(F_{1,168}=\right.$ $5.561, p>0.05)$ in both bee subspecies. The rates of stored sealed honey varied according to subspecies, month, and year (Figure 4 and Table 1). In the native 


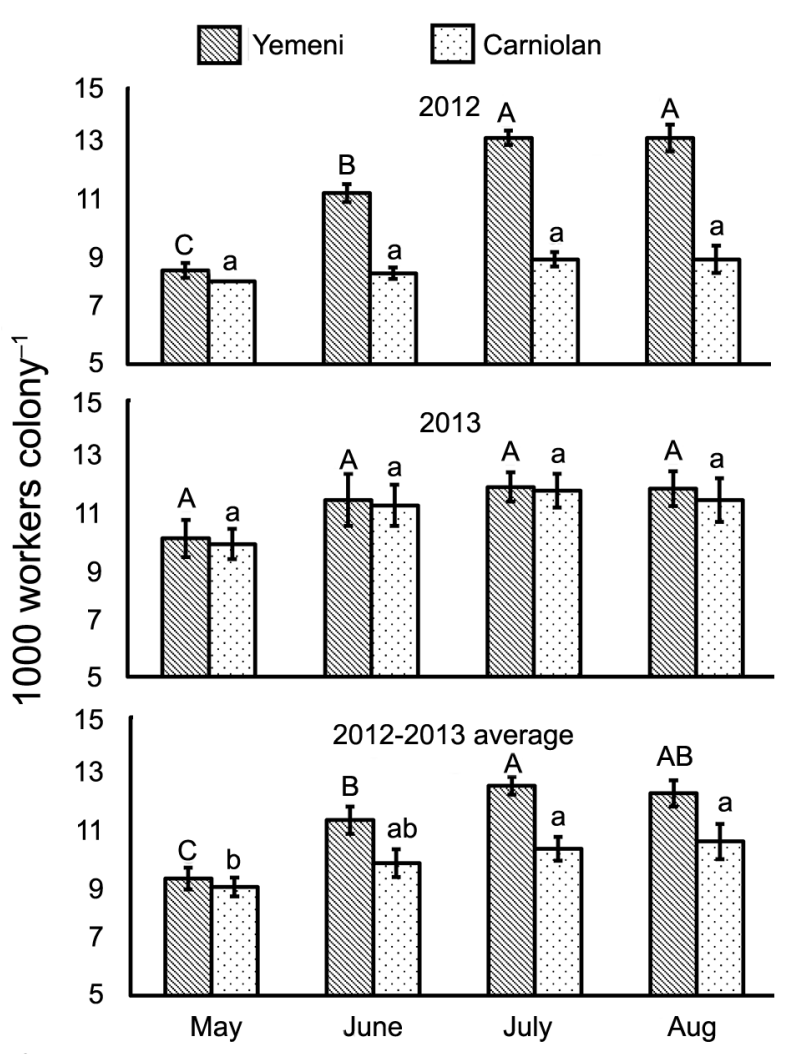

*Means with the same letter in the same column chart are not significantly different $(p>0.05)$.

Figure 3 - Monthly values of worker bee population rates (mean \pm standard error) of Yemeni (Apis mellifera jemenitica) and Carniolan (A.m. carnica) honey bee colonies during the Talh (Acacia gerrardii Benth.) nectar flow season (May to Aug) in Central Arabia.

Yemeni colonies, the sealed honey area during Aug (1567 $\pm 132 \mathrm{~cm}^{2}$ colony ${ }^{-1}$ ) was 18.5 and 1.5 times more than the sealed honey areas during May and June, respectively. Likewise, the sealed honey area of the Carniolan colonies during Aug (1457 $\pm 164 \mathrm{~cm}^{2}$ colony $\left.{ }^{-1}\right)$ totaled 22.6, 2.0, and 1.4 times more than the sealed honey areas during May, June, and July, respectively (Figure 4).

\section{Honey yield}

The honey yield of the Yemeni colonies (5653 \pm $419 \mathrm{~g} \mathrm{colony}^{-1}$ ) was 1.2 times more than that of the Carniolan colonies $\left(3995 \pm 954\right.$ g colony $\left.^{-1}\right)$ one week before flow cessation. However, by one week after flow cessation the subspecies were still not significantly different $\left(F_{1,18}=2.047, p>0.05\right)$. Talh honey yield varied according to harvest time, bee subspecies and year, which served to underline the importance of harvesting time.

After the Talh nectar flow ceased, the amount of Talh honey decreased $\left(F_{1,38}=4.729, p \leq 0.05\right)$ by $13 \%$ compared to the amount before flow cessation. In particular, this reduction was very sharp in Yemeni colonies (19\%) compared to Carniolan colonies (7 \%).

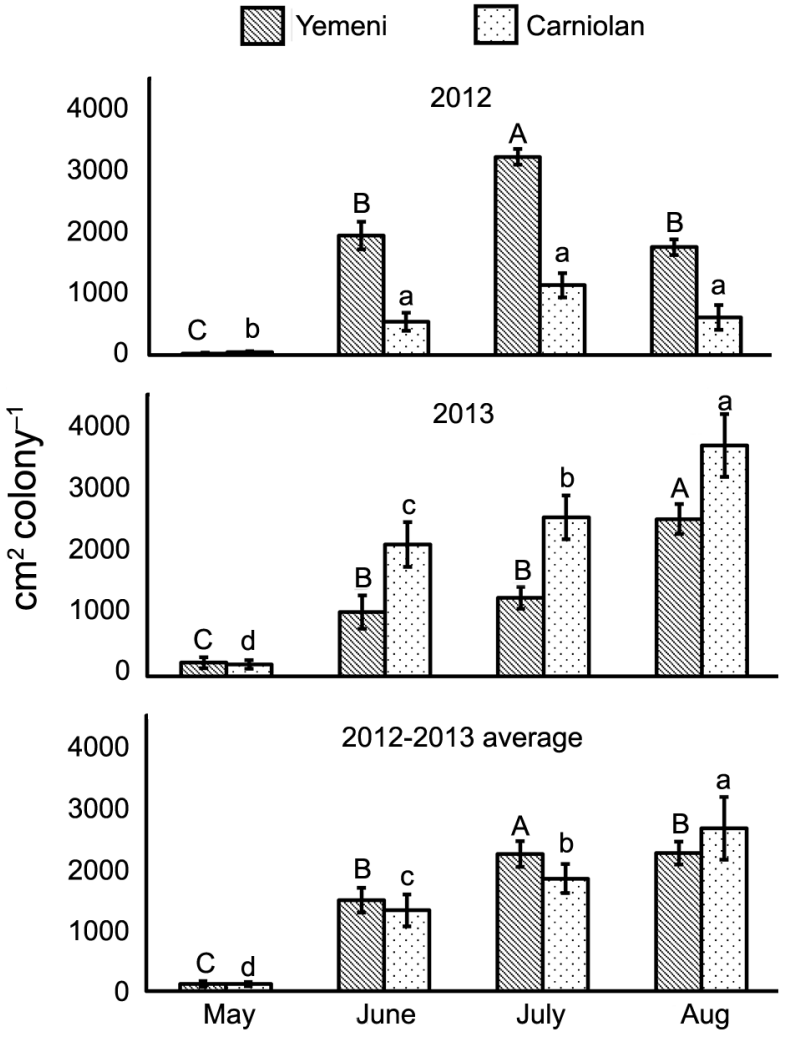

*Means with the same letter in the same column chart are not significantly different $(p>0.05)$.

Figure 4 - Monthly values of sealed honey storage rates (mean \pm standard error) of Yemeni (Apis mellifera jemenitica) and Carniolan (A.m. carnica) honey bee colonies during the Talh (Acacia gerrardii Benth.) nectar flow season (May to Aug) in Central Arabia.

\section{Discussion}

The different honey bee subspecies dealt with the hot-dry-windy weather differently during the Talh nectar flow season in the study area. Honey bee colonies regulate their nest temperature between 33 and $36^{\circ} \mathrm{C}$ (Kronenberg and Heller, 1982; Petz et al., 2004), which was often far below the temperatures found outside the colony in the present study. Thus, bee colonies have been thought to suffer mostly from the need to maintain these lower in-colony temperatures.

The nectar-rich Talh forage boosted honey bee colonies in this hot-dry-windy weather. In other words, the availability of flowers rich in nectar obscured the negative effect of summer weather on the performance of the studied honey bee subspecies. The values of brood, bee bread, honey, and bee population obtained in the current study were slightly higher than those recorded by El-Sarrag (1993). However, Abou-Shaara et al. (2013) also reported lower values of the same parameters during similar weather conditions, but on a less rich source of bee plants compared to Acacia gerrardii. 
The seasonal Talh honey yield from the tested colonies was approximately $4 \mathrm{~kg}$ colony $^{-1}$ during the Talh nectar flow. The Talh honey price reached US\$ $65 \mathrm{~kg}^{-1}$ in Saudi Arabia (Adgaba et al., 2014) and, consequently, Talh honey yield from a single colony reached approximately US\$ 260. In apiculture management and planning, it is important to evaluate the honey yield of a particular area or flow (as we did in the present study) as well as the potential honey yield of a particular forage (e.g., Adgaba et al., 2012, 2014). The annual yields are far higher than this value because modern beekeeping is mainly migratory beekeeping (Sharma and Bhatia, 2001). Beekeepers in Saudi Arabia migrate from their apiaries on average approximately five times per year (Adgaba et al., 2014).

Delaying the honey harvest for a few days after the season ended decreased the Talh honey yield. Honey bee colonies consume part of their honey stock after the season ends owing to the presence of brood (Woyke, 1992). In the present findings, honey reduction in the Yemeni colonies was greater than in the Carniolan colonies because the Yemeni colonies had both a larger brood area and a higher bee population. Similar results were observed by Alqarni et al. (2014).

Yemeni colonies produced brood, stored bee bread and retained a bee population greater than those of Carniolan colonies during Talh nectar flow; however, both subspecies produced similar honey yields $(p>0.05)$. This trend was also documented by Alqarni et al. (2011) and Abou-Shaara et al. (2013). The superiority of the Yemeni bees under the hot-dry-windy weather conditions could be due to their physiological and behavioral adaptation to those conditions. Adaptive traits such as less water loss (Alqarni, 2006), better egg hatchability (Al-Ghamdi et al., 2014), and active foraging behavior during hot periods (Ali, 2011; Abou-Shaara et al., 2012) have been documented. The high brood production of Yemeni bees could explain their low honey yield, as the brood consumes the stored honey towards the end of the season.

The Yemeni honey bee subspecies has evolved in south Arabia close to A. $m$. scutellata and the two subspecies coexist in East Africa; however, they suffer somewhat drastic conditions, namely, hot-dry weather and the annual lack of bee forage during certain months. Both subspecies have high migration rates under these conditions as they escape to other potentially more suitable locations (Nuru et al., 2002). However, this migration was documented under traditional beekeeping practices in East Africa, and included the use of traditional bee hives. No migration was recorded during the present study, either in the tested colonies or in the huge apiaries in the study area. This lack of migration may be attributable to the nectar-rich Talh bloom. Nuru et al. (2002) stated that food depletion bears the primary responsibility for migration-not the hot-dry weather. Additionally, it could be argued that the lack of migration is due, in part, to the modern beekeeping practices used in Central Arabia. These practices include modern hiving, routine inspections, and a constant water supply. On the other side of the globe, Winston et al. (1979) reported high migration rates in Africanized honey bees $(A . m$. scutellata) in South America, which they attributed to the hot-dry weather and declines in food source. A. m. jemenitica and $A$. m. scutellata share similar morphological and physiological adaptations to hot-dry weather $(A$. m. jemenitica: Alqarni, 2006; Ali, 2011; Abou-Shaara et al., 2012; Al-Ghamdi et al., 2014 and A. m. scutellata: Southwick and Heldmaier, 1987; Southwick and Moritz, 1987; Human et al., 2006).

Even a slight improvement in weather and forage conditions enhanced the Carniolan bees similar to the Yemeni subspecies in terms of both performance and productivity. During 2013, the Carniolan colonies elevated their sealed brood, bee population, and honey productivity rates close to those of the Yemeni colonies (Table 1). The slight enhancement in weather and Talh flowering quality during 2013 could thus explain the improvement in the performance and productivity of the Carniolan bees during the same year. The Yemeni colonies had distinct advantages in extremely hot-drywindy climates compared to the Carniolan colonies (Abou-Shaara et al., 2013). However, the superiority of the standard Carniolan bees appeared when the weather became slightly less drastic. A similar trend was observed in Venezuela in a comparison of Africanized and European honey bees (Rinderer et al., 1985). It could be that there is an adaptive cost for the Yemeni subspecies, which makes them far better than Carniolan bees in drastic weather, but under less drastic conditions, these costs affect them. This kind of ecological concept needs more studies to be clarified.

The brood rearing, food storage and bee population of honey bee colonies fluctuated throughout the Talh nectar flow season (from May to Aug). Two variables could be responsible for this monthly variability: weather and forage. The weather varied slightly as the months passed. Talh forage quality can be represented by the nectar secretion rate, and great differences were found in the nectar secretion rate between months throughout the flow season (Alqarni et al., 2015). Consequently, it is thought that the quality of Talh forage is the major cause of monthly variations in the strength of honey bee colonies.

This study recommends that beekeepers should benefit from Talh forage and other summer bee flora in the subtropics because the bees are still able to collect honey in such environment. Therefore, beekeepers should select the honey bee subspecies with care in order to capitalize on such flows. For example, Yemeni bees are better able to maintain colony strength compared to Carniolan bees even though both groups can produce similar amounts of honey. Talh honey should be harvested a few days before the cessation of seasonal flow. In addition, extreme care should be taken in the hiving and housing of honey bees during subtropical summers. Enhanced hiving practices may reduce the negative effects of the predominantly hot-dry-windy weather. 
The honey bees were able to maintain remarkable rates of brood rearing, food storage, and bee population during Talh nectar flow despite the hot-dry-windy conditions of the subtropical desert. The native subspecies constructed stronger colonies than the Carniolan imports; nevertheless, their honey yield was approximately equal. Therefore, Yemeni bees may be the best evolved to benefit from Talh nectar flow because they were able to maintain the strength of their colonies even in such harsh weather. The nectar-rich bee flora enhanced the performance of the honey bee colonies, overcoming the negative effects of hot-dry-windy summers of the subtropical desert.

\section{Acknowledgments}

This Project was funded by the National Plan for Science, Technology and Innovation (MAARIFAH), King Abdulaziz City for Science and Technology, Kingdom of Saudi Arabia, Award Number (12-AGR2510-02). The authors appreciate the valuable comments and suggestions of the Associate Editor and the four anonymous reviewers. We appreciate the necessary assistance by beekeepers; Mr. Faiz Ergaf and Mr. Mohamed Assodi during the field work.

\section{References}

Abou-Shaara, H.F.; Al-Ghamdi, A.A.; Mohamed, A.A. 2012. Tolerance of two honey bee races to various temperature and relative humidity gradients. Environmental and Experimental Biology 10: 133-138.

Abou-Shaara, H.F.; Al-Ghamdi, A.A.; Mohamed, A.A. 2013. Honey bee colonies performance enhanced by newly modified beehives. Journal of Apicultural Sciences 57: 45-57.

Abrol, D.P. 2006. Diversity of pollinating insects visiting litchi flowers (Litchi chinensis Sonn.) and path analysis of environmental factors influencing foraging behavior of four honeybee species. Journal of Apicultural Research 45: 180-187.

Adgaba, N.; Al-Ghamdi, A.; Shenkute, A.G.; Ismaiel, S.; Al-Kahtani, S.; Tadess, Y.; Ansari, M.J.; Abebe, W.; Abdulaziz, M.Q.A. 2014. Socio-economic analysis of beekeeping and determinants of box hive technology adoption in the kingdom of Saudi Arabia. The Journal of Animal \& Plant Sciences 24: 1876-1884.

Adgaba, N.; Awad, M.A.; Al-Ghamdi, A.; Alqarni, A.S.; Radloff, S.E. 2012. Nectar of Ziziphus spina-christi (L.) Wild (Rhamnaceae): dynamics of secretion and potential for honey production. Journal of Apicultural Sciences 56: 5-15.

Alfarhan, A.H. 2001. A floristic account on Raudhat Khuraim Central Province Saudi Arabia. Saudi Journal of Biological Sciences 8: 80-103.

Al-Ghamdi, A.; Abou-Shaara, H.F.; Mohamed A.A. 2014. Hatching rates and some characteristics of Yemeni and Carniolan honey bee eggs. Journal of Entomology and Zoology Studies 2: 6-10.

Ali, M.A.M. 2007. Effect of supplementary feeding on brood production and population development of honey bee (Apis mellifera jemenitica). Minufia Journal of Agricultural Research 32: 915-932.
Ali, M.A.M. 2011. Comparative study for evaluating two honey bee races, Apis mellifera jemenitica (indigenous race) and Apis mellifera carnica (Carniolan race) in brood production, population development and foraging activity under the environmental conditions of the central region of the Kingdom of Saudi Arabia. Annals of Agricultural Sciences 56: 127-134.

Al-Khalifa, A.S.; Al-Arify, I.A. 1999. Physicochemical characteristics and pollen spectrum of some Saudi honeys. Food Chemistry 67: 21-25.

Alqarni, A.S. 2006. Tolerance of summer temperature in imported and indigenous honeybee Apis mellifera L. Races in central Saudi Arabia. Saudi Journal of Biological Sciences 13: 123-127.

Alqarni, A.S.; Balhareth, H.M.; Owayss, A.A. 2014. Performance evaluation of indigenous and exotic honey bee (Apis mellifera L.) races in Assir region, southwestern Saudi Arabia. Saudi Journal of Biological Sciences 21: 256-264.

Alqarni, A.S.; Hannan, M.A.; Owayss, A.A.; Engel, M.S. 2011. The indigenous honey bees of Saudi Arabia (Hymenoptera, Apidae, Apis mellifera jemenitica Ruttner): their natural history and role in beekeeping. ZooKeys 134: 83-98.

Alqarni, A.S.; Owayss, A.A.; Mahmoud, A.A. 2016. Physicochemical characteristics, total phenols and pigments of national and international honeys in Saudi Arabia. Arabian Journal of Chemistry 9: 114-120. DOI: 10.1016/j. arabjc.2012.11.013

Alqarni, A.S.; Awad, M.A.; Owayss, A.A. 2015. Evaluation of Acacia gerrardii Benth. (Fabaceae: Mimosoideae) as a honey plant under extremely hot-dry conditions: flowering phenology, nectar yield and honey potentiality. Journal of Animal and Plant Sciences 25: 11-19.

Alqarni, A.S.; Awad, M.A.; Raweh, H.S.A.; Owayss, A.A. 2015. Pollination ecology of Acacia gerrardii Benth. (Fabaceae: Mimosoideae) under extremely hot-dry conditions. Saudi Journal of Biological Sciences. DOI: 10.1016/j.sjbs.2015.09.019

Aref, M.I.; Elkhalifa, K.F.; El-Juhany, L.I. 2003. A dendrological key for identification of Acacia species growing in Saudi Arabia and Northern Sudan. Journal of King Abdulaziz University for Meteorology, Environment and Arid Land 14: 87-94.

Buco, S.M.; Rinderer, T.E.; Sylvester, H.A.; Collins, A.M.; Lancaster, V.A.; Crewe, R.M. 1987. Morphometric differences between South American Africanized and South African (Apis mellifera scutellata) honey bees. Apidologie 18: 217-222.

Corbet, S.A.; Fussell, M.; Ake, R.; Fraser, A.; Gunson, C.; Savage, A.; Smith, K. 1993. Temperature and pollination activity of social bees. Ecological Entomology 18: 17-30.

Dag, A.; Eisikowitch, D. 1999. Ventilation of greenhouses increases honey bee foraging activity on melon, Cucumis melo. Journal of Apicultural Research 38: 169-175.

Dharani, N. 2007. Field Guide to Acacias of East Africa. Random House, Cape Town, South Africa.

El-Sarrag, M.S.A. 1993. Some factors affecting brood rearing activity in honeybee colonies in the central region of Saudi Arabia. Journal of King Saud University 5: 97-108.

Hill, D.B.; Webster, T.C. 1995. Apiculture and forestry (bees and trees). Agroforestry Systems 29: 313-320.

Human, H.; Nicolson, S.W.; Dietemann, V. 2006. Do honeybees, Apis mellifera scutellata, regulate humidity in their nest? Naturwissenschaften 93: 397-401. 
Jeffree, E.P. 1958. A shaped wire grid for estimating quantities of brood and pollen in combs. Bee World 58: 105-118.

Keasar, T.; Shmida, A. 2009. An evaluation of Israeli forestry trees and shrubs as potential forage plants for bees. Israel Journal of Plant Sciences 57: 1-16.

Kronenberg, F.; Heller, H.C. 1982. Colonial thermoregulation in honey bees (Apis mellifera). Journal of Comparative Physiology B 148: 65-76.

Nuru, A.; Al-Ghamdi, A.; Tadesse, Y.; Getachew, A.; Awad, M.A.; Ansari, M.J.; Owayss, A.A.; Mohammed, S.A.; Alqarni, A.S. 2016. Nectar secretion dynamics and honey production potentials of some major honey plants in Saudi Arabia. Saudi Journal of Biological Sciences 24: 180-191. DOI: 10.1016/j. sjbs.2016.05.002

Nuru, A.; Amssalu, B.; Hepburn, H.R.; Radloff, S.E. 2002. Swarming and migration in the honey bees (Apis mellifera) of Ethiopia. Journal of Apicultural Research 41: 35-41.

Peel, M.C.; Finlayson, B.L.; McMahon, T.A. 2007. Updated world map of the Köppen-Geiger climate classification. Hydrology and Earth System Sciences 11: 1633-1644.

Petz, M.; Stabentheiner, A.; Crailsheim, K. 2004. Respiration of individual honeybee larvae in relation to age and ambient temperature. Journal of Comparative Physiology B 174: 511518.
Rachad, S.M.; Parker, R.L. 1958. Pollen as a limiting factor in brood rearing and honey production during three drought years 1954, 1955 and 1956. Transactions of the Kansas Academy of Science 61: 237-248.

Rinderer, T.E.; Hellmich, R.L.; Danka, R.G.; Collins, A.M. 1985. Male reproductive parasitism: a factor in the Africanization of European honey-bee populations. Science 228: 1119-1121.

Sharma, R.; Bhatia, R. 2001. Economics of stationary and migratory beekeeping in Himachal Pradesh. Agricultural Science Digest 21: 196-197.

Southwick, E.E.; Heldmaier G. 1987. Temperature control in honey bee colonies. BioScience 37: 395-399.

Southwick, E.E.; Moritz, R.F.A. 1987. Effects of meteorological factors on defensive behaviour of honey bees. International Journal of Biometeorology 31: 259-265.

Winston, M.L.; Otis, G.W.; Taylor, O.R. 1979. Absconding behavior of the Africanized honeybee in South America. Journal of Apicultural Research 18: 85-94.

Woyke, J. 1992. Diurnal flight activity of African bees Apis mellifera adansonii in different seasons and zones of Ghana. Apidologie 23: 107-117. 